\title{
A Comparative Study about Knowledge, Attitude, Practice of Antibiotic Use and Perceptions of the Possible Causes of Resistance between Final Year Undergraduate Students and Postgraduate Pharmacy Students
}

\author{
Ruaa Natiq Yahya ${ }^{1}$, Muntazar Mohammed Wasmi \\ ${ }^{1}$ Assisstant Lecturer, Department of Clinical Pharmacy, College of Pharmacy, University of Baghdad, \\ ${ }^{2}$ Stager at College of Pharmacy, College of Pharmacy, University of Baghdad
}

\begin{abstract}
Background: Antibiotic resistance is a problem leading to difficulty in treating microbial infections that may occur due to many causes. For the important pharmacist role as a reference for the information and the ability to access to medications, they are vital members in lowering the development of antibiotic resistance, and also they support the proper use and control of antibioticsmisuse. Our goal is comparing the knowledge, attitude, practice of undergraduate and postgraduate pharmacy students and their perceptions about the causing factors of antibiotic resistance in Iraq.
\end{abstract}

Method: A cross sectional study was conducted involving the final year bachelor and postgraduate (master and Philosophical doctor) students from different private and public pharmacy universities in Iraq. An adjusted questionnaire was administrated to 233 students electronically and the results obtained were analyzed by using SPSS 20 for Windows Descriptive. A significant difference was found in the knowledge of antibiotic between undergraduate and postgraduate(Master and Philosophical doctor) students (Mean knowledge score 5.32 versus 5.92 respectively, $\mathrm{p}<0.001$ ). Attitude data also showed a higher positive attitude of postgraduate students according to antibiotic use and resistance when compared to undergraduate students (Mean attitude score: 2.97 versus 2.92 respectively, $\mathrm{p}<0.05$ ). Significant difference was observed in practices of the comparative students groups regarding to the frequency of self- medication, reason, sources of antibiotic use and in terms of disease condition where they used $(\mathrm{p}<0.05)$. Continuous mutation and gene changes of micro-organism taken the higher percentages answere $d$ yes for the undergraduate students while the limited restrictions on antibiotic usage taken the higher percentages answere $d$ yes for the postgraduate students (89.1\% and $98.5 \%$ respectively).

Conclusion: We can conclude from data of our study that there is a significant difference in the knowledge, attitude, practice of antibiotic use and perceptions of the possible causes of resistance between postgraduate (master and Philosophical doctor) and undergraduate (fifth year bachelor) pharmacy students when assessing the use of antibiotic and related resistance. This will help to determine the educational requirements for pharmacy students in colleges of Iraq for better understanding and dealing with the antibiotic resistance problem in the future.

Keywords: Knowledge, Attitudes, Practice, Antibiotics, Pharmacy Students.

\section{Introduction}

\section{Corresponding Author:}

\section{Ruaa Natiq Yahya}

Assisstant Lecturer, Department of Clinical Pharmacy,

College of Pharmacy, University of Baghdad

e-mail: ruaa.yahia@copharma.uobaghdad.edu.iq
From the important events in the development of the medical field is the discovery of antibiotics which has a great effect on human life over the world. It helped to manage the dangerous disease or do surgeries with a high success rate for saving human life. The death due 
to previous high mortality infections is now under better control $^{(1)}$

High frequently used drugs often associated with irrational use are antibiotics. The most reported risk factor for the development of resistant pathogens is the over antibiotic use $\mathrm{e}^{(2)}$. There is a direct relation between the over usage of antibiotics and related resistance where populations who use less antibiotics develop lower amount of resistance to bacteria ${ }^{(3)}$ Antimicrobials overusecan change the human's normal flora which may lead to the multiplication of pathogenic bacteria and increase susceptibility to infections ${ }^{(4)}$.However, unnecessary antibiotic prescribing remains highly common also in developed countries where higher than a $5^{\text {th }}$ of all antibiotic prescriptions for patients are written for upper respiratory tract, bronchial and viral infections ${ }^{(}$

This antibiotic resistance is a big problem leading to difficulty in treating bacterial infections. This resistance caused by multiple reasons which include selfantimicrobial treatments without prescription, over-thecounter selling of antibiotics, low regulation of antibiotic prescriptions, expensive medical consultations, the knowledge and attitudes of patients towards antibiotic use, self-treatment,the knowledge and experiences of doctor and patient preference interaction. ${ }^{(5-7)}$

As a result multidrug-resistant (MDR) bacteria is accompanied with longer hospital stays, lower quality of life (QoL), additional fees for the healthcare department, and increased deaths ${ }^{(8-10)}$. There is an increasing need to push the scientific understanding of the factors associated with antibiotics use requiring efforts for managing the use of antibiotics have been directed toward the physician, protocols, and educational programs ${ }^{(11)}$.

Also, data about of health practitioners perceptions towards the use and resistance of antibiotics could be a baseline, such as, for urgent interventions including the development of national and international antibiotics policies and antimicrobial stewardship $\operatorname{program}^{(12)}$. The concept of antimicrobial stewardship including any intervention that required for the optimization of antimicrobial therapies for every single patient and to prevent the overuse and misuse of these medications ${ }^{(13)}$.

For the vital role of pharmacist in terms of the information and dispensing of medications, they have an essential role in the issue of antibiotic resistance, and to support the rational use and control of antibiotics. Gaps between pharmaceutical education on antibiotics and the use of them have been identified in previous studies ${ }^{(14-18)}$ with one common factor was the belief that antibiotics are effective in treating the common cold and other viruses. However, most pharmacy students believed a strong knowledge of antibiotics was important for their later careers and required more education in this field ${ }^{(19)}$. In this study, our goals were to assess Iraqis undergraduate and postgraduate pharmacy students' knowledge,attitude,practice of antibiotic use, and their perceptions about the causes of antibiotic resistance.

\section{Method}

The current cross-sectional study was carried out between final year undergraduate pharmacy students and postgraduate (master and Phd) pharmacy students who were studying in different private and public pharmacy colleges in Iraq. .Electronic copy of the questionnaire was used and posted in the social media for groups of the fifth stage and postgraduate pharmacy students from different Iraqi universities. This study carried out on a period of 4 months from January to April, 2020. Each student required approximately 10 minutes to fill the demographic data and research questionnaire completely.

There were five sections in the questionnaire. The first one was about the demographic characteristics of students (age, gender, place of residence, and governorate).

Section two, comprised of six questions, assessing the knowledge of participants about their use of antibioticsby asking questions regarding the effectiveness, adverse effects, resistance and economical concerns, policy issues and implication of antibiotic use. Every response was scored as: True $=1$ which represents the correct answer, False $=0$ and Don't Know $=0$ which are wrong answer. The highest possible score of knowledge section was 6 and the minimum was 0 . A total knowledge section score of $\geq 4$ was taken as a good knowledge while score of $<4$ as a poor knowledge. The same criteria were also used for scoring the $6^{\text {th }}$ section of this questionnaire in assessing the possible causes of antibiotic resistance.

The third section was about students' attitude towards antibiotic use and resistance. It consisted from five questions which was measured on 4 pointlikert scale. Scores were given to strongly agree $=1$, agree $=2$, disagree $=3$ and strongly disagree $=4$. A mean score of $\geq$ 3 was taken as a positive attitude while score of $<3$ as a negative attitude. 
The fourth section was assessing the students' practices towards self-medication with antibiotics in 4 terms (frequency, reason, source, and the disease condition were they used).. The fifth part of the questionnaire evaluated the students about possible causes of antibiotic resistance they believe. It consisted from 7 questions answere $d$ with either yes or no.

Data were statistically analyzed using SPSS 20 for Windows Descriptive analysis was employed, and the results were expressed in frequency and percentages. Chi-squares test was used to calculate the p-value regarding dependent and independent and a value $<0.05$ was considered as a significant difference between them.

\section{Results}

A total number of 233 pharmacy students were participated in this study with mean age $( \pm \mathrm{SD})$ of 26.13 $( \pm 3.302)$ years. The number of male students was 35 (15.0\%) while that of female students was 198 (85.0\%). Students divided into two groups: Group (1): include 101 (43.3\%) Final year undergraduate bachelor pharmacy students,Group (2): include 132 (56.7\%) postgraduate (Master and Phd) pharmacy students as shown in table 1.

The majority of postgraduate students was apparent to be correctly answere $\mathrm{d}$ all the knowledge related questions especially on question about taking antibiotics too often are less likely to work in the future $(100 \%$ correct answer). On the other hand, the least percentage of correct answers for the undergraduate students answere $d$ correctly on the same question (76.2\%). The knowledge score mean was higher in postgraduate than undergraduate (5.92 versus 5.32 respectively). The responses of all knowledge questions mentioned in Table- 2 .

\section{Table 1: Demographic characteristics of students participated in the study}

\begin{tabular}{|l|c|c|}
\hline Parameter & \multirow{2}{*}{ No. (\%) } & Mean $( \pm$ SD) \\
\cline { 1 - 1 } Age & & $\mathbf{2 6 . 1 3}( \pm \mathbf{3 . 3 0 2})$ \\
\hline Gender & & \\
Female & & \\
Undergraduate & $78(77.2 \%)$ & \\
Postgraduate & $120(90.9 \%)$ & \\
Total & $198(85.0 \%)$ & \\
Male & & \\
Undergraduate & $23(22.8 \%)$ & \\
Postgraduate & $12(9.1 \%)$ & \\
Total & $35(15.0 \%)$ & \\
\hline Place of residency & & \\
Rural & $30(12.9 \%)$ & \\
Urban & $203(87.1 \%)$ & \\
\hline Stage & & \\
Undergraduate & $101(43.3 \%)$ & \\
Postgraduate & $132(56.7 \%)$ & \\
\hline College & & \\
Private college & $125(53.6 \%)$ & \\
Publiccollege & $108(46.4 \%)$ & \\
\hline
\end{tabular}

SD: Standard deviation

Table 2: Knowledge questions regarding antibiotic use with students' percentages who respond correctly $(\mathrm{N}=\mathbf{2 3 3})$

\begin{tabular}{|l|c|c|c|}
\hline \multirow{2}{*}{ Knowledge Questions** } & \multicolumn{2}{|c|}{ Correctly Answere d (\%) } \\
\cline { 2 - 4 } & $\begin{array}{c}\text { Undergraduate (5th stage) } \\
\text { pharmacy students }\end{array}$ & $\begin{array}{c}\text { Postgraduate } \\
\text { (Master \& Phd) students }\end{array}$ & $130(98.5 \%)$ \\
\hline $\begin{array}{l}\text { Irrationaluse of antibiotics can lead to ineffective } \\
\text { treatment }\end{array}$ & $94(93.1 \%)$ & $128(97 \%)$ & 0.034 \\
\hline $\begin{array}{l}\text { Irrational use of antibiotics can lead to increase adverse } \\
\text { effects }\end{array}$ & $87(86.1 \%)$ & $131(99.2 \%)$ & 0.002 \\
\hline $\begin{array}{l}\text { Inappropriate antibiotics use may increase emergence } \\
\text { of bacterial resistance }\end{array}$ & $94(93.1 \%)$ & $130(98.5 \%)$ & $<.01$ \\
\hline $\begin{array}{l}\text { Irrational use of antibiotics can lead to additional } \\
\text { medical cost on the patient }\end{array}$ & $87(86.1 \%)$ & $132(100 \%)$ \\
\hline $\begin{array}{l}\text { Taking antibiotics more frequently can lead to less } \\
\text { efficacy in the future }\end{array}$ & $77(76.2 \%)$ & $<0.001$ \\
\hline $\begin{array}{l}\text { Antibiotic resistance is a serious problem that facing } \\
\text { patients health around the world }\end{array}$ & $96(95 \%)$ & $<0.001$ \\
\hline
\end{tabular}

*P value calculated by Chi-square test.**Knowledge score mean $( \pm$ SD) for undergraduate students was $5.32( \pm 1.095)$ and for postgraduate students was $5.92( \pm 0.318)$ with significant difference $(\mathrm{P}<0.001)$ 
Data showed that the positive attitude of postgraduate students was higher than that of undergraduate students [Attitude score mean $( \pm \mathrm{SD})$ was $2.97( \pm 0.14)$ versus 2.92 $( \pm 0.53)$ respectively] and it was statistically significant in all attitude related statements $(\mathrm{p}<0.05)$. The responses of undergraduate and postgraduate students towards attitude questions are summarized in Table 3.

Table 3: Students' attitude towards antibiotic use $(\mathbf{N}=\mathbf{2 3 3})$

\begin{tabular}{|c|c|c|c|c|}
\hline \multirow[b]{2}{*}{ Question } & \multicolumn{2}{|c|}{ Positive Attitude Count (\%) } & \multirow{2}{*}{$\begin{array}{c}\text { Mean } \\
\text { attitude } \\
\text { score (SD) }\end{array}$} & \multirow[b]{2}{*}{ P-value* } \\
\hline & $\begin{array}{c}\text { Undergraduate }\left(5^{\text {th }} \text { stage }\right) \\
\text { pharmacy students }\end{array}$ & $\begin{array}{l}\text { Postgraduate (Master \& } \\
\text { Phd) Pharmacy students }\end{array}$ & & \\
\hline $\begin{array}{l}\text { I take antibiotics when having cold to } \\
\text { prevent worsening of the illness }\end{array}$ & $81(80.2 \%)$ & $127(95.2 \%)$ & $2.99(0.59)$ & $<0.001$ \\
\hline $\begin{array}{l}\text { I take antibiotics when having fever to make } \\
\text { me better more quickly }\end{array}$ & $78(77.2 \%)$ & $128(97 \%)$ & $2.94(0.53)$ & $<0.001$ \\
\hline $\begin{array}{l}\text { Patient should stop taking antibiotics as } \\
\text { soon as he/she feels better }\end{array}$ & $77(76.3 \%)$ & $129(97.7 \%)$ & $3.03(0.69)$ & $<0.001$ \\
\hline $\begin{array}{l}\text { Missing one or two doses will not contribute } \\
\text { to microbial resistance to antibiotics }\end{array}$ & $56(55.5 \%)$ & $125(94.7 \%)$ & $2.81(0.36)$ & $<0.001$ \\
\hline $\begin{array}{l}\text { We can commonly use antibiotics since its } \\
\text { safe }\end{array}$ & $81(80.2 \%)$ & $127(97 \%)$ & $2.97(0.56)$ & $<0.001$ \\
\hline
\end{tabular}

*P value calculated by Chi-square test., **Attitude score mean $( \pm \mathrm{SD})$ for undergraduates students was $2.92( \pm 0.53)$, and for postgraduates students was $2.97( \pm 0.14)$.

Self-antibiotic practices of students is illustrated in table-4. Significant difference was found between the final year bachelor pharmacy students and postgraduate pharmacy students when asked about practices in terms of frequency of self- administration, reason, sources of medication and disease for which antibiotics were taken $(\mathrm{p}<0.05)$.

Table 4: Self-Antibiotics practices of students $(\mathrm{N}=\mathbf{2 3 3})$

\begin{tabular}{|c|c|c|c|c|}
\hline $\begin{array}{l}\text { Self-antibiotic } \\
\text { use }\end{array}$ & Category & $\begin{array}{c}\text { Undergraduate } \\
\text { pharmacy }\left(5^{\text {th }} \text { Stage }\right) \\
\text { Students* }(\%)\end{array}$ & $\begin{array}{c}\text { Postgraduate } \\
\text { pharmacy (Master \& } \\
\text { Phd) students* }(\%)\end{array}$ & P value $* *$ \\
\hline \multirow{4}{*}{$\begin{array}{l}\text { How often } \\
\text { you take } \\
\text { self-medication }\end{array}$} & Occasionally & $46(45.5 \%)$ & $100(75.8 \%)$ & \multirow{4}{*}{$<0.001$} \\
\hline & Weekly & $3(3 \%)$ & $3(2.3 \%)$ & \\
\hline & Rarely & $49(48.5 \%)$ & $28(21.2 \%)$ & \\
\hline & Never & $3(3 \%)$ & $1(0.8 \%)$ & \\
\hline \multirow{4}{*}{ Reason } & Disease is simple & $46(45.5 \%)$ & $22(16.7 \%)$ & \multirow{4}{*}{$<0.001$} \\
\hline & Higher treatments' cost in clinics & $2(2 \%)$ & $3(2.3 \%)$ & \\
\hline & Previous exposure to same health problem & $50(49.5 \%)$ & $106(80.3 \%)$ & \\
\hline & There is no hospitals in the nearby & $3(3 \%)$ & $1(0.8 \%)$ & \\
\hline \multirow{4}{*}{ Source } & Family, friends or neighbours & $9(8.9 \%)$ & $3(2.3 \%)$ & \multirow{4}{*}{$<0.001$} \\
\hline & Retail pharmacy shops & $30(29.7 \%)$ & $25(18.9 \%)$ & \\
\hline & Previous prescription & $38(37.6 \%)$ & $95(72 \%)$ & \\
\hline & Others & $24(23.8 \%)$ & $9(6.8 \%)$ & \\
\hline \multirow{4}{*}{ Disease conditions } & Cough/cold/flu and other respiratory problems & $77(76.2 \%)$ & $120(90.9 \%)$ & \multirow{4}{*}{0.013} \\
\hline & Wound infection & $7(6.9 \%)$ & $6(4.5 \%)$ & \\
\hline & GIT related problems(such as diarrhea) & $8(7.9 \%)$ & $3(2.3 \%)$ & \\
\hline & Eye/ear infection & $9(8.9 \%)$ & $3(2.3 \%)$ & \\
\hline
\end{tabular}

*Students answere $\mathrm{d}$ in yes, ${ }^{* *} \mathrm{P}$ value calculated by Chi-square test 
In table 5 the participants' response towards the possible causes of resistance is illustrated. Significant difference was observed between the final year bachelor pharmacy students and postgraduate pharmacy students when asked about all the questions of possible cause of antibiotic resistance $(p<0.05)$. Continous mutation and gene changes of micro-organism taken the higher percentages answere $d$ yes for the undergraduate students while the limited restrictions on antibiotic usage taken the higher percentages answere $d$ yes for the postgraduate students ( $89.1 \%$ and $98.5 \%$ respectively).

Table 5: Students perception of possible causes of antibiotic resistance

\begin{tabular}{|l|c|c|c|}
\hline \multirow{2}{*}{ Following are the possible causes of resistance } & \multicolumn{2}{|c|}{ Respondents answere d Yes (\%) } \\
\cline { 2 - 4 } & $\begin{array}{c}\text { Undergraduate (5th stage) } \\
\text { pharmacy students }\end{array}$ & $\begin{array}{c}\text { Postgraduate } \\
\text { (Master \& Phd) students }\end{array}$ & $118(89.4 \%)$ \\
\hline Adminstration of antibiotics for non bacterial infections & $75(74.3 \%)$ & $120(90.9 \%)$ & $<0.001$ \\
\hline Unnecessary broader spectrum antibiotics use & $76(75.2 \%)$ & $115(87.1 \%)$ & $<0.001$ \\
\hline $\begin{array}{l}\text { Shorter period of antibiotics administration than } \\
\text { standard duration }\end{array}$ & $80(79.2 \%)$ & $124(93.9 \%)$ & $<0.001$ \\
\hline Poor infection control measures & $78(77.2 \%)$ & $128(97 \%)$ & 0.003 \\
\hline $\begin{array}{l}\text { Continous mutation and gene changes of micro } \\
\text { organism }\end{array}$ & $90(89.1 \%)$ & $120(90.9 \%)$ & $<0.001$ \\
\hline $\begin{array}{l}\text { Longerperiod of antibiotics administration than } \\
\text { standard duration }\end{array}$ & $63(62.4 \%)$ & $130(98.5 \%)$ & $<0.001$ \\
\hline Limited restrictions for antibiotic prescription and use & $73(72.3 \%)$ & & $<$ \\
\hline
\end{tabular}

*P value was calculated by Chi-square test

\section{Discussion}

Results of our study showed that postgraduate students(master and Phd) had better knowledge about antibiotic usage in comparison to undergraduate bachelor students. Speaking on the knowledge, undergraduate bachelor students, as opposed to postgraduate students(master and Phd), answere d poorly on question about taking antibiotics more frequently can lead to less efficacy in the future. This low knowledge of undergraduate students was consistent with result obtained with other study in Australia and Sri Lanka ${ }^{(20)}$. So,there is a need for additional educational courses forunder graduate bachelor students for improving their understanding about the real causes of microbial resistance and improving antimicrobial therapy success $^{(21)}$. However, both study groups considered to have a good knowledge when compared to a study applied to non-medical students ${ }^{(22)}$.

This study showed a higher positive attitude of postgraduate students when compared to undergraduate bachelor students believing that antibiotic treatment course should be standard and not stopped when patient feels better ( $97.7 \%$ versus $76.3 \%$ respectively), and also the antibiotics are not safe and can not be commonly used ( $97 \%$ versus $80.2 \%$ respectively). The biggest difference about the positive attitude between the postgraduate and undergraduate pharmacy students was in the question (Missing one or two doses will not contribute to microbial resistance to antibiotics) with percentages of $94.7 \%$ and $55.5 \%$ respectively. This gap in percentages give an indication that postgraduate students have more awareness about antibiotic resistance in contrast to undergraduate students who may misuse antibiotic treatment .

Lower self-antibiotic medication was found among undergraduate and postgraduate pharmacy students in this study when compared to results obtained from non-medical colleges. Non-medical colleges believed that antibiotics could be prescribed for even viral infections ${ }^{(23)}$. When comparing between the students groups in our study the results showed higher practice of antibiotic self-medication with postgraduate students than undergraduate students. The highest percentage was (occasional self-medication with antibiotics) for postgraduate students $(75.8 \%)$ while (rare selfmedication with antibiotics) for undergraduate students 
(48.5\%). These results are consistent with previous study on Nigerian and Sudanese undergraduate students about self-medication with both antibiotics and analgesic also $^{(24,25)}$. However, in this study, these high results were associated with more experience with the previous disease and depending on past doctor prescription for the same medical condition as illustrated in table- 4 .

Antibiotic were found to be used frequently among medical students all over the world which has health and economic adverse event as showed in previous studies $^{(26-28)}$. Although this considered to be lower than nonmedical students since pharmacy and medical students received some educational courses during their study. These educational courses reflect the appropriate usage of such medications by them but still we cannot deny the high amount of antibiotic prescribing ${ }^{(29)}$.

In our study, when students asked about their perception for the possible causes for antibiotic resistance postgraduate students answere $\mathrm{d}$ better on reasons related to limited restrictions for antibiotic prescribing while undergraduate students the answer was the mutation in micro-organism. Good perception with postgraduate students may be related to the experience that they had by dealing with prescriptions in pharmacies or hospitals where they work. Continuous detection of resistant microbial strain could solve and control the problem of antibiotic resistant to some extent in addition lead to lower costs and hospitalization.

Indirect factors for unnecessary antibiotic use could be due to patients demand,wrong diagnosis and communication skills ${ }^{(30-32)}$.Communication skills should be introduced the syllabus of medical colleges in order to teach students how to convince patients for rational antibiotic use and reflect their attitude to reduce patient expectation about antibiotic treatment ${ }^{(33)}$.

\section{Conclusion}

The results of this study showed significant difference in the knowledge, attitude, practices of antibiotic use and perceptions of the possible causes of resistance between undergraduate (fifth year bachelor) pharmacy students and postgraduate (master and Phd) when assessing the use of antibiotics and related resistance. These results can be used to determine the aspects for antimicrobial's knowledge requirements for both undergraduate and postgraduate pharmacy students in colleges of Iraq for better understanding the proposed causes of antimicrobial drug resistance. This study can become the basis for subsequent research for the possible educational courses that can be applied to undergraduate and postgraduate students in pharmacy colleges.

Ethical Clearance: All the students included in this study were older than 18 years, and they reveal voluntary permission to participation. There were no personal identifiers during the administration and collection of the questionnaire to rule out any personal identification.

\section{Source of Funding: Self}

Conflict of Interest: There is no conflict of interest

\section{References}

1. Limaye D, Naware S, Bare P, Dalvi S, Dhurve $\mathrm{K}$, Sydymanov A, et al. Knowledge, attitude and practices of antibiotic usage among students from Mumbai University. Int J Res Med Sci. 2018;6(6):1908.

2. Al-Nema ZM. Trend of Antibiotics Usage in the Intensive Care Unit in the Medical City in Baghdad. Iraqi J Pharm Sci,. 2016;25(1):50-8.

3. Kalungia AC, Mwambula H, Munkombwe D, Marshall S, Schellack N, May C, et al. Antimicrobial stewardship knowledge and perception among physicians and pharmacists at leading tertiary teaching hospitals in Zambia: implications for future policy and practice. J Chemother. 2019;31(78):378-87.

4. Yusef D, Babaa AI, Bashaireh AZ, Al-Bawayeh HH, Al-Rijjal K, Nedal M, et al. Knowledge, practices \& attitude toward antibiotics use and bacterial resistance in Jordan: A cross-sectional study. Infect Dis Heal. 2018;23(1):33-40.

5. Dutt H, Sarkhil M, M A, Singh G. A comparative knowledge, attitude, and practice study of antimicrobial use, self-medication and antimicrobial resistance among final year students of MBBS, BDS, and BSc Nursing at a tertiary care hospital at Kannur. Natl J Physiol Pharm Pharmacol. 2018;8(9):1305.

6. Jairoun A, Hassan N, Ali A, Jairoun O, Shahwan M. Knowledge, attitude and practice of antibiotic use among university students: A cross sectional study in UAE. BMC Public Health. 2019;19(1):18 .

7. Lokhasudhan G, Nasim I. Knowledge, attitude, and practice survey on usage of antibiotics among 
dental practitioners in southern region of India. $\mathrm{J}$ Adv Pharm Educ Res. 2017;7(2):160-2.

8. Gajdács M, Paulik E, Szabó A. Knowledge, attitude and practice of community pharmacists regarding antibiotic use and infectious diseases: A cross-sectional survey in Hungary (KAPPhA-HU). Antibiotics. 2020;9(2).

9. Shah P, Shrestha R, Mao Z, Chen Y, Chen Y, Koju P, et al. Knowledge, attitude, and practice associated with antibiotic use among university students: A survey in Nepal. Int $\mathrm{J}$ Environ Res Public Health. 2019;16(20).

10. Benameur T, Al-Bohassan H, Al-Aithan A, AlBeladi A, Al-Ali H, Al-Omran H, et al. Knowledge, attitude, behaviour of the future healthcare professionals towards the self-medication practice with antibiotics. J Infect Dev Ctries. 2019;13(1):5666.

11. Al-Shibani N, Hamed A, Labban N, Al-Kattan R, Al-Otaibi H, Alfadda S. Knowledge, attitude and practice of antibiotic use and misuse among adults in Riyadh, Saudi Arabia. Saudi Med J. 2017;38(10):1038-44.

12. Chaw PS, Höpner J, Mikolajczyk R. The knowledge, attitude and practice of health practitioners towards antibiotic prescribing and resistance in developing countries-A systematic review. J Clin Pharm Ther. 2018;43(5):606-13.

13. Inácio $\mathrm{J}$, Barnes LM, Jeffs $\mathrm{S}$, Castanheira $\mathrm{P}$, Wiseman M, Inácio $\mathrm{S}$, et al. Master of Pharmacy students' knowledge and awareness of antibiotic use, resistance and stewardship. Curr Pharm Teach Learn. 2017;9(4):551-9.

14. Dhingra S, Khan M, Maharaj S, Pandey S, Patel I, Ahmad A. Knowledge, attitude and practice of B.Sc. Pharmacy students about antibiotics in Trinidad and Tobago. J Res Pharm Pract. 2015;4(1):37.

15. Ahmad A, Khan MU, Moorthy J, Jamshed SQ, Patel I. Comparison of knowledge and attitudes about antibiotics and resistance, and antibiotics selfpracticing between Bachelor of Pharmacy and Doctor of Pharmacy students in Southern India. Pharm Pract (Granada). 2015;13(1):1-7.

16. Jamshed SQ, Elkalmi R, Rajiah K, Al-Shami AK, Shamsudin SH, Siddiqui MJA, et al. Understanding of antibiotic use and resistance among final-year pharmacy and medical students: A pilot study. J Infect Dev Ctries. 2014;8(6):780-5.
17. Rajiah K, Ren WS, Jamshed SQ. Evaluation of the understanding of antibiotic resistance among Malaysian pharmacy students at public universities: An exploratory study. J Infect Public Health. 2015;8(3):266-73.

18. Justo JA, Gauthier TP, Scheetz MH, Chahine EB, Bookstaver PB, Gallagher JC, et al. Knowledge and attitudes of doctor of pharmacy students regarding the appropriate use of antimicrobials. Clin Infect Dis. 2014;59(Suppl 3):S162-9.

19. Nisabwe L, Brice H, Umuhire MC, Gwira O, Harelimana JDD, Nzeyimana Z, et al. Knowledge and attitudes towards antibiotic use and resistance among undergraduate healthcare students at University of Rwanda. J Pharm Policy Pract. 2020;13(1):1-8.

20. Sakeena MHF, Bennett AA, Carter SJ, McLachlan AJ. A comparative study regarding antibiotic consumption and knowledge of antimicrobial resistance among pharmacy students in Australia and Sri Lanka. PLoS One. 2019;14(3):1-14.

21. Paterson Davenport LA, Davey PG, Ker JS, Finch R, Harden R, Holmes B, et al. An outcome-based approach for teaching prudent antimicrobial prescribing to undergraduate medical students: Report of a Working Party of the British Society for Antimicrobial Chemotherapy. J Antimicrob Chemother. 2005;56(1):196-203.

22. Seid MA, Hussen MS. Knowledge and attitude towards antimicrobial resistance among final year undergraduate paramedical students at University of Gondar, Ethiopia. BMC Infect Dis. 2018;18(1):18.

23. Azevedo MM, Pinheiro C, Yaphe J, Baltazar F. Portuguese students' knowledge of antibiotics: A cross-sectional study of secondary school and university students in Braga. BMC Public Health. 2009;9:1-6.

24. Auta A, Banwat SB, Sariem CN, Shalkur D, Nasara B, Atuluku MO. Medicines in pharmacy students' residence and self-medication practices. J Young Pharm. 2012;4(2):119-23.

25. Awad AI, Eltayeb IB. Self-medication practices with antibiotics and antimalarials among Sudanese undergraduate university students. Ann Pharmacother. 2007;41(7-8):1249-55.

26. Hu Y, Wang X, Tucker JD, Little P, Moore M, Fukuda K, et al. Knowledge, attitude, and practice 
with respect to antibiotic use among Chinese medical students: A multicentre cross-sectional study. Int J Environ Res Public Health. 2018;15(6).

27. Williams A, Crawford K. Self-medication practices among undergraduate nursing and midwifery students in Australia: a cross-sectional study. Contemp Nurse. 2016;52(4):410-20.

28. Fejza A, Kryeziu Z, Kadrija K, Musa M. Pharmacy students' knowledge and attitudes about antibiotics in Kosovo. Pharm Pract (Granada). 2016;14(1):14.

29. Dixit A, R Mudaliyar V, Adiyodi A, Pathak A, Veer Singh C. A comparative, questionnaire based crosssectional study on self medication practice among medical and paramedical students at a rural tertiary care teaching hospital. Indian J Pharm Pharmacol. 2020;7(1):19-25.

30. Bagger K, Nielsen ABS, Siersma V, Bjerrum L.
Inappropriate antibiotic prescribing and demand for antibiotics in patients with upper respiratory tract infections is hardly different in female versus male patients as seen in primary care. Eur J Gen Pract. 2015;21(2):118-23.

31. Teixeira Rodrigues A, Roque F, Falcão A, Figueiras A, Herdeiro MT. Understanding physician antibiotic prescribing behaviour: A systematic review of qualitative studies. Int $\mathrm{J}$ Antimicrob Agents. 2013;41(3):203-12.

32. Coenen S, Michiels B, Renard D, Denekens J, Van Royen P. Antibiotic prescribing for acute cough: The effect of perceived patient demand. Br J Gen Pract. 2006;56(524):183-90.

33. Mangione-Smith $\mathrm{R}$, Elliott $\mathrm{MN}$, Stivers $\mathrm{T}$, McDonald LL, Heritage J. Ruling out the need for antibiotics: Are we sending the right message? Arch Pediatr Adolesc Med. 2006;160(9):945-52. 